\title{
Kontruksi Agrowisata Kelompok Tani Durian di Desa Kemuningsari Lor Kecamatan Panti Kabupaten Jember
}

\author{
Drs. Joko Mulyono, M.SI \\ Fakultas Ilmu Sosial dan Ilmu Politik Universitas Jember \\ gusmoel@gmail.com
}

\author{
Akhmad Munif Mubarok \\ Fakultas Ilmu Sosial dan Ilmu Politik Universitas Jember \\ Munif.fisip@gmail.com
}

\begin{abstract}
Abstrak
Otimalnya pengelolaan potensi durian dan meningkatnya kesejahteraan masyarakat di kemuningsari lor menjadi bagian tujuan diselenggarakannya kegiatan pengabdian ini kontruksi agrowisata durian menjadi konsep yang diusung untuk mencapai tujuan tersebut, beberapa kegiatan yang menjadi upaya untuk mengkonstruksi terbentuknya agrowisata durian diantaranya adalah Sosialisasi Organisasi dan Kelembagaan, Pembentukan Organisasi dan Kelembagaan, Pelatihan Manajemen Wisata, Studi Banding Agrowisata, Konstruksi Tata Kelola dan Tata Ruang Agrowisata, Peningkatan Kualitas Produk Melalui Pelatihan Pembibitan dan Pencegahan Hama Penyakit, Pemberian Bibit Durian pada Komunitas Petani, Mengoptimalisasi Pemanfaatan Website, Pemaparan Pekembangan Agrowisata dan Inisiasi Pembuatan Perdes Agrowisata, Menyusun Instrumen dan Pelaksanan Monev Tahap I. Keseluruhan kegiatan tersebut menjadi upaya untuk menyiapkan masyarakat dan mempersiapkan sumberdaya agrowisata dalam mendorong terjadinya agrowisata durian di kemuningsari lor. LKM agrowisata durian sebagai organisasi dan kelembagaan yang telah dibentuk diharapkan mampu menjadi media bagi masyarakat dan komunitas petani durian dalam mengkoptimalkan potensi durian dan potensi lain di desa kemuningsari lor.
\end{abstract}

Kata Kunci : Komunitas Petani Durian, Agrowisata Durian, Lembaga Keswadayaan Masyarakat

\begin{abstract}
The optimal management of durian potential and the improvement of community welfare in Kemuningsari Lor are part of the objectives of this community service activity. The construction of durian agro-tourism is a concept that is carried out to achieve this goal, some activities that are an effort to construct the formation of durian agro-tourism include Organizational and Institutional Socialization, Organization Formation and the formation of the durian. Institutional, Tourism Management Training, Comparative Study of Agrotourism, Construction of Agrotourism Management and Spatial Planning, Product Quality Improvement through Nursing Training and Prevention of Disease Pests, Provision of Durian Seedlings in Farmer Communities, Optimizing Website Utilization, Exploration
\end{abstract}


of Agro Tourism Development and Initiation for Agro Tourism Regulation, Compiling Disease Prevention, Instrument and Implementation of Monitoring and Evaluation Phase I. The whole activity is an effort to prepare the community and prepare agro-tourism resources in encouraging the occurrence of durian agrotourism in emuningsari lor. Durian agro-tourism MFI as an organization and institution that has been formed is expected to be able to become a medium for the community and durian farmers community in optimizing the potential of durian and other potentials in Kemuningsari Lor village.

Keywords : Durian Farmer Community, Durian Agro Tourism, Community Self-Reliance Institution

\section{PENDAHULUAN}

Pertanian merupakan salah satu kekuatan bagi masyarakat Indonesia, sejalan dengan yang dikatakan Setyobudi (2007:22) bahwa peran strategis pertanian sejalan dengan tujuan pembangunan perekonomian nasional karena pertanian sejatinya mampu meningkatkan kesejahteraan masyarakat, mempercepat pertumbuhan ekonomi, mengurangi kemiskinan; mampu menyediakan lapangan kerja; dan mampu memelihara keseimbangan sumberdaya alam lingkungan hidup. Problematika yang sering dihadapi oleh petani berupa banyaknya petani hanya puas mampu bercocok tanam bukan puas karena pendapatan dari hasil pertaniaannya. Kondisi tersebut berkaitan dengan musim atau cuaca yang tidak menentu ditambah persoalan pupuk dan obat-obatan pertanian yang mulai langka dan mahal, dan juga harga hasil panen yang selalu mengalami fluktuatif.

Marolop Nainggolan Kepala Biro Hubungan Masyarakat, Kementrian Perdagaan dalam Kompas.com mengungkapkan, setidaknya terdapat lima masalah yang dihadapi petani. Pertama, sempitnya rata-rata penguasaan lahan oleh petani, sehingga petani tidak dapat memproduksi hasil pertanian secara maksimal. Kedua, ketersediaan dan keterjangkauan saprodi (pupuk, bibit, pestisida). Ketiga, akses petani terhadap perbankan sebagai alternatif pembiayaan utama sangat rendah, sehingga petani terjerat sistem ijon dan tengkulak. Keempat, lemahnya organisasi petani yang mampu menyuarakan aspirasi sekaligus memperjuangkan keluhan petani. Kelima, sumber daya manusia petani sangat rendah. Permasalahan dari sektor pertanian muncul karena kualitas SDM petani cenderung masih rendah, sehingga sulit menyerap pengetahuan dan keterampilan untuk meningkatkan produktivitas usaha, termasuk jika harus berhubungan dengan teknologi.

Desa Kemuningsari Lor merupakan salah satu desa di Kecamatan Panti yang memiliki banyak potensi dalam pertanian, salah satu potensi unggulan yang dapat diandalkan diantaranya durian. Di beberapa dusun yang ada di Desa Kemuningsari Lor terdapat beberapa petani durian yang diakui mampu 
mengahasilkan durian berkualitas dalam jumlah yang banyak, selain itu buah durian yang dihasilkan telah mampu dipasarkan diberbagai daerah baik lokal maupun nasional. Namun yang sangat disayangkan justru tidak banyak masyarakat yang tertarik untuk mengembangkan pertanian tersebut, disisi lain usaha pertanian durian di desa Kemuningsari Lor masih belum banyak mendapat sentuhan teknologi dan menejemen pengelolaan usaha pertanian durian yang modern dan memadai, sehingga masih sangat memungkinkan untuk dapat dikembangkan menjadi lebih baik lagi, yang pada akhirnya mampu menjadikan usaha pertanian durian sebagai sumber kekuatan bagi kesejahteraan masyarakat di kemuningsari lor.

Durian sebagai komuditas unggulan di Desa Kemuningsari Lor selama ini telah mampu memasarkan hingga keberbagai daerah. Rendahnya minat masyarakat dalam mengolah komuditas unggulan tersebut mengakibatkan masyarakat belum mengembangkan durian menjadi produk olahan, sehingga masih belum mampu bertahan lama dan mampu menembus pasar yang lebih jauh, oleh karena itu tersebut menjadi tantangan bagi pengembagan usaha pertanian durian di kemuningsari lor.

Salah satu upaya yang dilakukan oleh salah satu kelompok tani di Dusun Sumbersari, Desa Kemuningsari Lor, dibantu oleh salah kelompok KKN tematik wisata dan wirausaha Universitas Jember tercetus inisiatif untuk menjadikan usaha pertanian durian dijadikan sebagai edukasi agrowisata durian yang diaktualisasikan melalui Agrowisata Gubuk Durian. Keberadaan Agrowisata Gubuk Durian diharapkan mampu menjadi upaya yang sistemik untuk menumbuhkan kesadaran dan menarik minat masyarakat secara luas dan khususnya masyarakat sekitar untuk mengenal dan memahami proses pembibitan, penanaman, hingga perawatan untuk menghasilkan durian yang berkualitas tinggi sehingga mampu mendatangkan keuntungan. Selain itu terbangunnya konsep wisata edukasi durian ini juga diharapkan menjadi sarana bagi petani durian untuk memasarkan hasil pertaniannya dan menggerakkan ekonomi masyarakat sekitar dalam bidang yang lainnya.

Ada beberapa tahapan yang telah mampu dilakukan komunitas dalam menunjang inisiatif tersebut, salah satu diantaranya telah membentuk kelembagaan dan keorganisasian dalam usaha mereka, sebagai langkah awal suksesi untuk mewujudkan apa yang telah menjadi tujuan dan cita-cita mereka. Kelompok atau komunitas yang mereka bentuk kemudian mereka sepakati untuk diberi nama Gubuk Durian Dian Kurnia pada tanggal 25 Agustus 2018 komunitas petnai durian dian kurnia telah berhasil melakukan peremian sebagai Agrowisata Gubuk Durian, adapun tujuan dari peresmian tarsebut untuk mendeklarasikan diri agar masyarakat dan pihak terkait dapat mengetahui adanya agrowisata yang 
dapat digunakan sebagai tempat edukasi sekaligus wisata, selain itu kegiatan tersebut dilakukan untuk menunjukkan komitmen dan untuk mendapatkan dukungan dari masyarakat luas serta pemerintah setempat.

Dian Kurnia dibangun untuk menjadi salah satu pusat pembibitan durian yang terdapat di Desa Kemuningsari Lor. Sebagai penangkar bibit durian, Dian Kurnia memiliki suplai bahan baku untuk produksinya. Suplai tersebut berasal dari kebun indukan untuk kemudian diperbanyak dengan metode vegetative, yang dianggap paling efektif untuk menjamin mutu pohon serta buah durian. Secara sederhana proses jalanya penangkaran bibit durian ini adalah dengan sistem reservasi, dimana bibit terlebih dahulu dipesan sesuai dengan jumlah serta jenis yang diinginkan oleh karenanya selama ini produksi bibit sangat tergantung dari pesanan yang diterima oleh penangkar. Tidak hanya dalam proses produksi yang masih konvensional, pemasaran bibit Dian Kurnia masih bisa dikatakan konvensional. Belum adanya sumberdaya yang memadai terkait pemasaran atau kurangnya kesadaran mengenai inovasi dalam pemasaran dianggap sebagai faktor yang membuat metode pemasaran masih konvensional.

Selain itu keorganisasian dan infrastruktur dian kurnia sebagai agrowisata durian masih perlu untuk ditingkatkan dan dikuatkan mengingat keorganisasian dan infrastrutur yang dimiliki masih sangat terbatas dan belum mengakomodasi kebutuhannya, masih belum terdapat ad/art, program kerja maupun tupoksi yang mampu dijadikan sebagai acuan dalam menjalankan keorganisasian mereka. Sedangkan infrastruktur yang tersedia hanya ada lahan, bibit yang masih belum dikelompokkan sesuai jenisnya, gubuk ditengah pematang yang mulai rapuh dan beberapa papan alakadarnya yang terpangpang dibeberapa sudut untuk menunjukkan keberadaan agrowisata durian dian kurnia dan usia bibit yang ditanam serta papan yang memberikan informasi alur pembibitan dan proses perawatan bibit.

Berangkat dari kondisi tersebut, revitalisasi pada kelengakapan keorganisasian yang dimiliki dian kurnia tentunya akan menjadi peluang untuk mampu mengatasi setiap persoalan dan tantangan yang dihadapi komunitas dalam mewujudkan keberdayaan masyarakat di desa kemuningsari lor khususnya dusun sumbersari dalam mengembangkan agrowisata gubuk durian, dengan terbentuknya struktur organisasi dan program kerja yang terbangun sesuai kebutuhan tentunya akan lebih memudahkan terwujudnya usaha pertanian durian sebagai komuditas utama yang mampu mensejahterakan masyarakat. oleh karena itu selain melengkapi sarana prasana dasar dan membangun sistem agrowisata yang kontektual untuk menunjang keberadaan agrowisata gubuk durian revitalisasi pada keorganisasian kelompok tani durian dian kurnia dirasa sangat penting untuk dilakukan. 


\section{METODE PENGABDIAN}

Metode yang digunakan dalam pelaksanaan pengabdian ini koordinasi, sosialisasi, dan pelatihan. Pelaksanaan kegiatan pengabdian dilakukan pada Kelompok Tani Durian Dian Kurnia yang ada di Dusun Sumbersari, Desa Kemunisari Lor, Kecamatan Panti dimulai tanggal 25 September 2018 sampai tanggal 11 Agustus 2019.

\section{HASIL}

Pengabdian Kontruksi Agrowisata Edukasi Pada Kelompok Tani Durian di Desa Kemuningsari Lor Kecamatan Panti, Kabupaten Jember, dalam hal ini dilakukan dalam 3 tahap, dan tahap peratama dalam pengabdian ini adalah membangun potensi, yang dilakukan dengan mempersiapkan berbagai perangkat pendukung untuk mempersiapkan durian sebagai komuditas utama dan menjadikan kemuningasari lor sebagai desa agrowisata durian. Adapaun berikut merupakan pelaksanaan pengabdian tahap pertama ini:

\section{Sosialisasi Organisasi dan Kelembagaan}

Tahap ini merupakan tahap awal yang dilakukan sebagai media yang diharapakan mampu membangunkan kesadaran masyarakat akan potensi, permasalahan dan upaya yang paling memungkinkan untuk dapat dilakukan. Hampir setiap rumah di desa Kemungsari Lor terdapat satu sampai dua pohon durian, selain itu juga terdapat komunitas dan perorangan yang diketahui selain sebagai petani durian juga sebagai pengembang bibit durian, yang konon bibit dan buah duriannya cukup banyak diminati dipasaran, bahkan diakui sampai kewalahan untuk memenuhi permintaan pasar, namun yang cukup disayangkan, potensi ini tidak berbanding lurus dengan pemahaman dan pengetahuan masyarakat, terbukti durian masih belum mampu dipahami sebagai komuditas utama yang menjanjikan, perawatan dan pengelolaan bibit ataupun buah durian masih menjadi kendala utama bagi masyarakat dan komunitas, sehingga sampai saat ini durian tidak mampu dioptimalisasi sebagai potensi yang memberdayakan.

Berangkat dari kondisi tersebut, sebagai upaya untuk menjadikan potensi durian di desa kemungsari lor mampu dioptimalisasi, maka pertama-tama kami bersama tim mengumpulkan dan menemui beberapa orang perwakilan dari komunitas petani durian dan perangkat desa menyampaikan beberapa hal terkait rencana-renacana pengabdian kami, hasil dari pertemuan tersebut kemudian kami 
menyepakati untuk mengagendakan pertemuan selanjutnya, yaitu dengan mengumpulkan para penggiat pertanian durian dan perwakilan pemerintahan desa untuk melakukan focus groups discution sebagai media dalam mengidentifikasi persoalan pemanfaatan durian sebagai potesi dan sosialisasi pentingnya organisasi dan kelembagaan sebagai media dalam mengoptimalisasi potensi.

Komunitas petani durian menyadari bahwa terbentuknya organisasi dan kelembagaan yang nantinya akan mereka bentuk akan mampu memberi harapan bagi mereka untuk lebih mengoptimalisasi potensi durian, sehingga harapan desa kemungningsari menjadi desa sentra durian dan menjadi desa agrowisata duriansatu-satunya di jember memungkinkan dapat diwujudkan.

\section{Pembentukan Organisasi dan Kelembagaan}

Menindaklanjuti hasil FGD yang telah dilakukan, masyarakat menyadari bahwa persoalan-persoalan yang selama ini dihadapi baik dalam pembibitan, perawatan, pengelolaan hingga pemanfaatan durian sebagai komuditas utama diyakini akan tertanggulangi dengan baik ketika petani durian memeliliki wadah organisasi dan tata kelembagaan yang akomodatif terhadap persoalan yang mereka hadapi. Sejalan dengan hal tersebut para perwakilan komunitas petani durian selanjutnya menyepakati untuk mengadakan pertemuan lanjutan sebagai upaya untuk menemukan bentuk organisasi dan kelembagaan yang tepat sesuai kebutuhan mereka.

Sebagai hasilnya bentuk kelembagaan pimpinan kolektif kolegial dipilih dan disepakati oleh komunitas petani dalam forum tersebut sebagai bentuk ideal organisasi dan kelembagaan mereka. Dalam model dan bentuk kelembagaan ini, keorgnisasiaanya dipimpin secara kolektif yaitu terdiri dari banyak orang yang disepakati oleh para anggota sebagai orang-orang yang dianggap memiliki kebijaksanaan. Cara pemilihan pimpinan kolektifpun melalui bertahapan yaitu penentuan kreteri calon pemimpin, penjaringan calon dan pemelihan calon. Adapun struktur keorganisasianya adalah sebagai berikut:

\section{a) Alur Pembentukan Organisasi dan Kelembagaan}

Alur ini merupakan gambaran alur yang dapat digunakan untuk menjadi acuan langkah dalam pembentukan organisasi dan kelembagaan di kemuningsari lor, adapun alurnya adalah sebagai berikut:

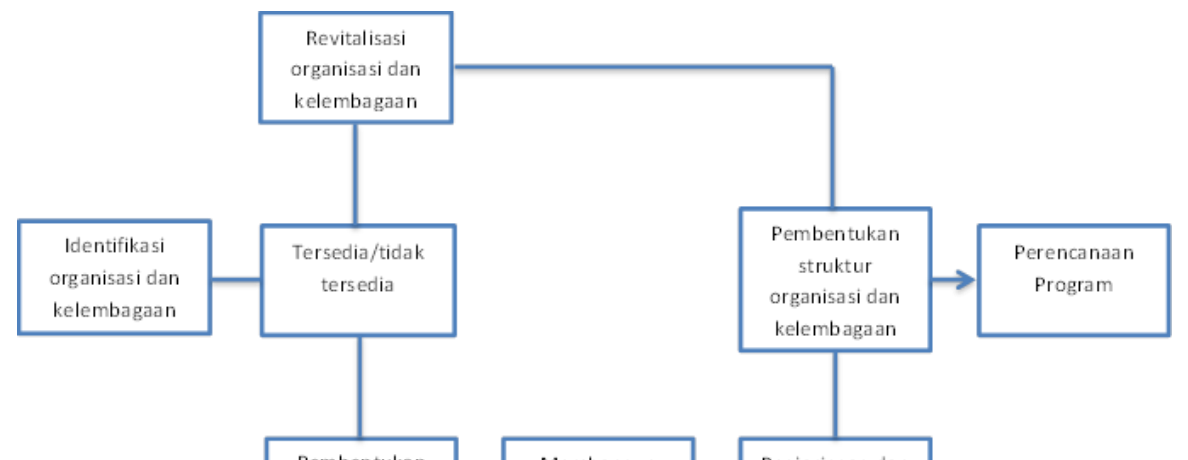




\section{b) Struktur Organisasi}

Struktur organisasi menjadi kebutuhan dalam kelengkapan keorganisasian, dan struktur organisasi memberi gambaran garis intruksi dan koordinasi antara satu dengan yang lainnya, adapun berikut merupakan bentuk struktur orgnasasi yang disepakati oleh komunitas petani durian di Kemuningsari Lor:

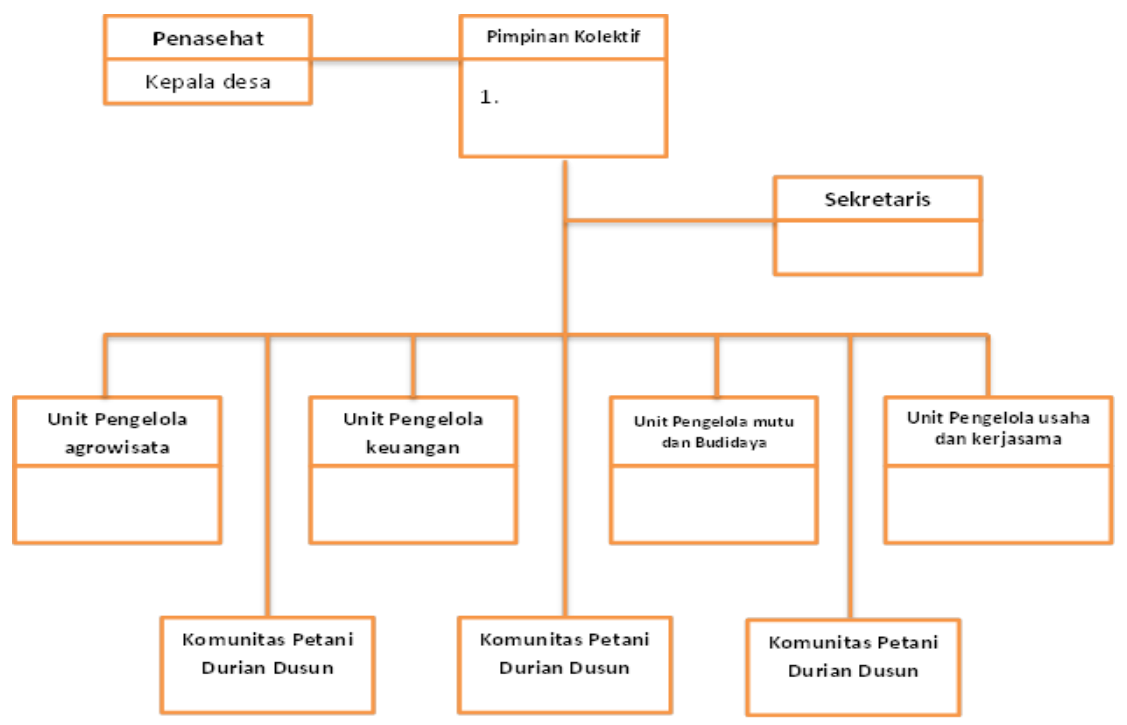

\section{Pelatihan Manajemen Wisata}

Berangkat dari potensi durian yang ada di Kemungsari Lor yang kurang mampu teroptimalisasi dengan baik, maka upaya-upaya optimalisasi atas hal tersebut diarasa perlu dilakukan, dan pelatihan menejemen pariwisata menjadi bagian untuk mempersiapkan masyarakat agar memiliki pemahaman dan pengetahuan dalam pengelolan wisata nantinya, mengingat agrowisata durian merupakan suatu konsep yang disepakati untuk mampu menjadi sarana dalam mengoptimalisasi potensi lokal masyarakat, dengan dijadikannya desa kemuningsari lor sebagai desa agrowisata durian diharapkan akan mampu menggerakkan ekonomi masyarakat, mengingat selain durian yang hampir tersedia dimasing-masing rumah penduduk. 
Adapun pelatihan menenjemen wisata seperti yang telah dijelaskan di atas, memiliki tujuan diantaranya untuk membangun pengetahuan masyarakat agar memiliki kapasitas dalam memanfaatkan potensinya sebagai agrowisata, dan juga untuk menstimulan masyarakat agar memiliki pemahaman bahwa agrowisata nantinya akan memberi banyak manfaat bagi masyarakat. Antusiasme masyarakat dalam legiatan ini ditunjukkan dengan banyaknya masyarakat yang bertanya pada narasumber dan diantara mereka juga merasa cukup optimis bahwa jika konsep ini terealisasi akan mampu memberi dampak perubahan pada ekonomi masyarakat. Pemahaman dan optimisme ini akan memberi banyak pengaruh pada sikap dan keseriuasan mereka dalam mewujudkan desa kemuningsari lor sebagai agrowisata durian. Berangkat dari pemaparan pemateri dan tim pengabdian masyarakat menyepakati bahwa konsep agrowisata yang mereka kehendaki adalah agrowisata durian yang berbasis komunitas di level desa bukan dusun seperti yang sebelumnya ditawarkan dalam program $\mathrm{kkn}$.

\section{Studi Banding Agrowisata}

Studi banding merupakan tahap lanjutan sebagai upaya untuk menemukan bentuk dan konsep agrowisata yang sesuai dengan kondisi geografis dan potensi kemuningsari lor, berdasar hasil identifikasi terdapat beberapa opsi lokasi studi banding, sehingga pada akhirnya disepakati di Desa Ngembal, Kecamatan Tutur Nongkojajar, Kabupaten Pasuruan sebagai lokasi studi banding.

Desa Ngembal ini sudah mampu dikelola dan masyarakat mampu memanfaatkan potensinya dengan baik, terbukti terdapat banyak home stay, dan hotel di daerah ini, selain itu juga ada agrowisata yang meawarkan konsep wisata yang tidak banyak dimiliki di daerah lain, karena mampu menonjolkan potensi lokalnya yaitu buah-buahan, sayur-sayuran dan pertenakan sapi perah. Sehingga wajar sekalipun jauh dari pusat kota lokasi studi banding cukup ramai dikunjungi pengunjung dari berbagai daerah. Terbukti tim pengabdian beserta perwakilan kelompok tani sempat kesulitan untuk mendapatkan tempat untuk menginap karena banyak hotel dan penginapan yang telah terisi penuh.

Atas pengalaman tersebut, pada akhirnya memberi kesan tersediri bagi tim pengabdian dan perwakilan petani durian kemuningsari lor, karena hal tersebut semakin menggugah optimisme masyarakat untuk terus melanjutkan apa yang direncanakan yaitu menjadikan kemudingsari lor sebagai desa agrowisata durian, dan dari hal tersebut juga diyakinin bahwa komunitas petani durian akan berkembang ketika mampu menjadikan desa kemuningsari lor dengan branding sebagai desa agrowisata durian, karena hal tersebut juga dapat dimanfaatkan 
sebagai sarana untuk mengenalkan durian sebagai komuditas utama dan potensi local lainnya seperti produk-produk hasil home industri masyarakat, kesenian.

\section{Konstruksi Tata Kelola dan Tata Ruang Agrowisata}

Lembaga keswadayaan desa yang telah terbentuk diharapkan mampu menjadi motor penggerak dalam mewujudkan kemunigsari lor sebagai desa agrowisata durian. Seperti yang tergambar dalam struktur organisasi lembaga keswadayaan masyarakat, dalam mewujudkan kemunigsari lor sebagai agrowisata durian adalah menjadikan durian sebagai komuditas utama di desa kemuningsari lor, karena sekalipun sudah banyak terdapat durian di setiap rumah penduduk, namun tidak semua penduduk atau masyarakat yang mengganggap durian layak untuk dikembangkan sebagai komuditas utama yang menguntungkan, terbukti banyak lahan yang dimiliki masyarakat tidak hanya ditanami tanaman durian, bahkan ada yang dibiarkan kosong.

Sebagai desa agrowisata durian tentunya ketersedian durian mutlak dibutuhkan baik bagi yang hanya ingin menikmati buah durian ataupun yang ingin belajar menanam, merawat dll, oleh karena itu tiga dusun di kemuningsari lor di dorong untuk mampu menyediakan hal tersebut, sehingga di masing-masing dusun didorong untuk membentuk komunitas petani durian, dimana komunitas itu nantinya yang akan menjadi pionir dalam membangun dusunnya untuk menjadikan durian sebagai komuditas utamannya, dan LKM sebagai induk organisasi bertanggung jawab dalam mengakomodasi berbagai kebutuhan yang meliputi perawatan, peningkatan kualitas mutu, maupun dalam mendistrubusi pengunjung pada masing-masing kelompok tani di masing-masing dusun.

Setiap pengunjung yang yang ingin ber-agropwisata durian pertama-tama mendaftarkan diri pada unit pengelola agrowisata durian, selanjutnya unit peneglola menunjuk satu diantara beberapa kelompok tani durian, dimana penunjukkan dilakukan secara bergantian, bagi kelompok yang sudah pernah dikunjungi pengunjung tidak akan ditunjuk kembali hingga semua kelompok telah mendapat giliran kunjungan pengunjung. Selanjutnya kelompok tani yang ditunjuk mengantarkan pengunjung kelokasi, dan melayani pengunjung sesuai kebutuhannya baik hanya sekedar menikmati buah durian langsung dibawah pohon maupun ingin belajar perawatan, pembibitan maupun pengolahan buah durian. Harga durian dan tarif jasa edukasi mengikuti kesepakatan yang telah disepakati dalam LKM hal tersebut dilakukan untuk memberi kenyamanan bagi setiap pengunjung dan juga untuk keberlangsungan organisasi. Adapun berikut alur agrowisata durian desa kemuningsari lor: 


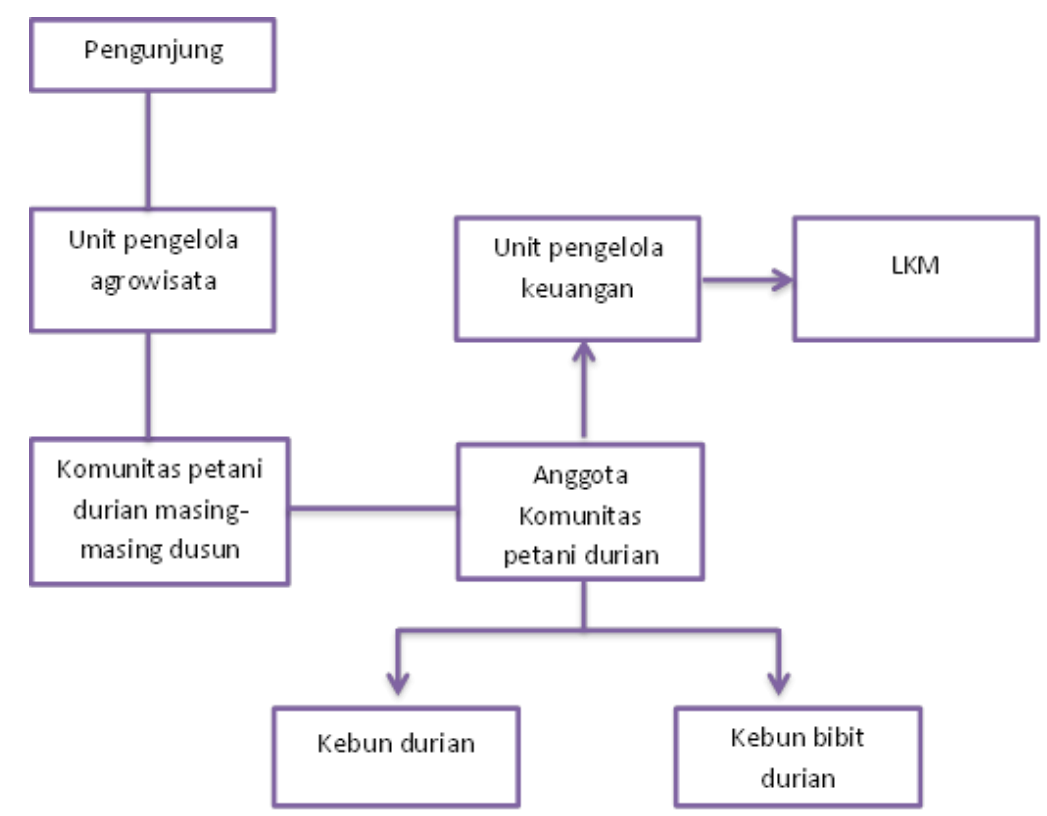

\section{Peningkatan Kualitas Produk Melalui Pelatihan Pembibitan dan Pencegahan Hama Penyakit}

Salah satu yang menjadi kendala dalam menjadikan durian sebagai komuditas unggulan di kemunigsari lor adalah hingga saat ini masyarakat komunitas kelompok tani rata-rata masih kesulitan mengatasi persoalan serangan hama penyakit khususnya pada bibit durian non lokal seperti durian montong atau oleh masyarakat kemuningsari disebut sebagai durian ontong. Penyakit yang muncul disampaikan oleh mereka diantaranya kutu batang, keluar cairan merah dan terdapat ulat di pohon, kondisi tersebut jika tidak segera diatasi menyebabkan kematian pada pohon.

Masyarakat menyayangkan hal tersebut di atas, karena jenis durian ontong banyak diminati masyarakat pecinta durian, selain rasanya manis jenis ini memiliki ketebalan pada buahnya. Masyarakat menghendaki jenis ini mampu bertahan dan berkembang dengan baik di kemuningsari lor karena memiliki nilai jual yang tinggi dan banyak yang meminati. Kondisi tersebut juga sama dirasakan pada komunitas durian di pasuruan lokasi studi banding, bahkan hingga saat ini mereka juga kesulitan menanggulangi persoalan tersebut.

Sejalan dengan hal tersebut di atas, kami tim pengabdian menindaklajuti dengan menghubungi salah satu pihak dari Universitas Jember yaitu Ir. Usmadi, M.P. Kepala UPT Agrotechnopark Universitas Jember untuk memberikan penyuluhan dan pelatihan pembibitan dan perawatan pohon durian, dalam 
kegiatan tersebut masyarakat sangat antusias karena masyarakat sangat berharap ada jalan keluar atas masalah yang mereka hadapi, dalam penyuluhan dan pelatihan tersebut disampaikan bahwa jenis bibit durian non-local diakui memang sulit untuk bertahan dilokasi yang bukan asalnya, karena strutur tanah, geografis dan cuaca sangat memberi pengaruh pada pertumbuhan mereka, kondisi yang berbeda tersebut juga memberi dampak pada kekebalan bibit ataupun pohon durian, sehingga wajar jika ada banyak kendala yang dihadapi ketika menanam bibit pohon durian jenis montong.

Dari pemaparan di atas, durian ontong sebenarnya dapat dikatakan untuk sementara ini masih belum dapat direkomendasi untuk dikembangkan dalam sekala besar di kemuningsari lor karena terlalu beresiko dan masih membutuhkan kajian-kajian lanjutan untuk menanganinya, oleh karena itu disarankan untuk lebih mengembangkan jenis durian lokal karena secara kualitas rasa sebenarnya tidak kalah dengan ontong, yang menjadi pembedanya hanya biji lebih kecil dan buah lebih besar.

\section{Pemberian Bibit Durian pada Komunitas Petani}

Sebagai upaya untuk menuju kemuningsari lor sebagai desa agrowisata durian, hal yang perlu dilakukan adalah mempersiapakan segala sesuatu yang mampu menunjang terjadinya hal tersebut, sebagai agrowisata durian bibit hingga buah durian menjadi tentunya wajib untuk tersedia, karena hal tersebut yang menjadi daya tawar utama dalam agrowisata tersebut, oleh karena itu untuk mewujudkannya, dalam rangka menunjang ketersedian tersebut tim pengabdian merasa perlu untuk memberikan sejumlah bibit durian pada komunitas petani durian di tiga dusun yang ada di kemuningsari lor. Hal tersebut dilakukan untuk menstimulan dan mendukung komitmen komunitas petani durian dalam menjadikan durian sebagai komuditas utama desa sehingga mampu segera merealisasikan desa kemunigsari lor sebagai desa agrowisata durian.

Pembelian bibit diserahkan langsung pada LKM menjaga terjadinya kecemburuan sosial diantara anggota LKM yang memiliki usaha pembibitan durian, tim hanya menentukan besaran harga sesuai pasaran dan jumlah bibit yang akan diberikan sesuai luasan lahan yang dibutuhkan untuk masing-masing komunitas dimasing-masing dusun. Penyerahan ini selain diikuti oleh semua anggota LKM dan semua komunitas petani durian di masing-masing dusun, juga diketahui dan disaksikan langsung oleh kepala desa sebagai pembina LKM, harapannya kapala desa sebagai pembina mampu mendukung dan juga turut mengawasi berjalannya rencana ini hingga mampu benar-benar terwujud, karena 
terwujudnya hal ini juga akan menjadi kemaslahatan dan kesejahteraan bagi seluruh warganya.

\section{Mengoptimalisasi Pemanfaatan Website}

Desa Kemuningsari Lor hampir disetiap rumah penduduk terdapat pohon durian, dan beberapa lahan seperti pekarangan dan kebun juga dimanfaatkan sebagai lahan untuk mengembangkan bibit durian dan sebaian lagi ditanami beberapa jenis durian, sekalipun demikian seperti yang telah disampaikan sebelumnya seringakali permintaan bibit dan buah durian dari berbagai daerah tidak mampu dipenuhi dengan baik, sehingga oleh sebagian petani durian hal ini dianggap sebagai peluang yang menjanjikan untuk dikembangkan, mengingat bibit dan buah durian kemuningsari lor banyak diminati oleh masyarakat di berbagai daerah.

Dian kurnia sebagai salah satu komunitas petani durian telah memiliki website yang digunakan sebagai salah satu media untuk memasarkan bibit yang dikembangkannya, pembuatan website dian kurnia di inisisasi oleh mahasiswa kkn agar bibit yang dikembangkan dian kurnia lebih dikenal oleh masyarakat luas, sebagai dampaknya penjualan bibit mereka menjadi lebih baik dari sebelumnya. Berdasarkan hal tersebut terbentuknya LKM sebagai lembaga penggerak potensi durian di kemuningsari lor tentunya juga membutuhkan website atau media online lain dalam mengkoptimalisasi pengelolaan potensi duriannya, oleh karena itu keberadaan website dian kurnia pada akhirnya disepakati untuk dioptimalkan sebagai website yang juga digunakan untuk mengenalkan dan mempromosikan agrowisata durian kemunigsari lor untuk sementara waktu hingga konsep dan bentuk agrowisata disahkan dan mampu ditunjang oleh perdes.

\section{Pemaparan Pekembangan Agrowisata dan Inisiasi Pembuatan Perdes Agrowisata}

Pada tahapan ini tim pengabdian melalui LKM mengundang seluruh kemunitas petani durian, perangkat desa, dan perwkilan masyarakat untuk hadir di balai desa dalam acara pemaparan perkembangan kontruksi agrowisata durian, agenda dalam kegiatan ini adalah memaparkan keseluruhan progres yang sudah di lakukan tim pengabdian bersama LKM terkait penyiapan dan persiapan pembentukan desa kemunigsari lor sebagai desa agrowisata durian, harapan dari kegiatan ini yaitu dipahami dan diketahui oleh pemerintah desa dan masyarakat sehingga apa yang telah menjadi rencana dan program dalam rangka menjadikan desa kemuningsari lor sebagai desa agrowisata durian mampu didukung dan mendorong tumbuhnya partisipasi masyarakat. 
Sebagai bentuk pertanggungjawaban pada masyarakat dan pemerintahan desa, tim pengabdian memaparkan keseluruhan tahapan beserta progresnya dalam pengabdian ini, termasuk juga rencana kedepan setelah tahap pertama ini dilakukan. Sebagai respons atas hal tersebut, sperti yang telah disampaikan dalam kesempatan sebelumnya kepala desa sangat berharap program ini dapat berjalan sesuai harapan dan sebagai kepala desa sangat mendukung harapan terjadinya desa kemuningsari lor sebagai desa agrowisata durian karena hal tersebut diyakini oleh kepala desa sebagai upaya yang sangat memungkinkan dan cukup memberi peluang bagi masyarakat, namun hal tersebut tidak mungkin terjadi jika tidak ada sinergitas, komitmen dan kerjasama dari semua lini termasuk pemerintahan desa, LKM, masyarakat dan juga universitas jember sebagai lembaga pendidikan yang banyak memiliki pakar yang mampu mendampingi dan mengedukasi masyarakat.

LKM sebagai lembaga yang didalamnya terdapat beberapa tokoh masyarakat yang juga menjadi petani durian cukup antusias dengan rencana tersebut mengingat hal tersebut bagi LKM sebagai organisasi penggerak dirasa sangat dibutuhkan untuk menunjang tugas mereka dalam mewujudkan mimpi dan hajad bersama tersebut. Sejalan dengan hal tersebut masyarakat juga turut menyambut baik atas apa yang telah dipaparkan oleh tim pengabdian dan LKM, masyarakat juga turut optimis karena durian mampu hidup dan tumbuh dengan baik di desanya selain itu mereka juga mengakui jika hampir seluruh penduduk memiliki tanaman durian dan sangat disayagkan jika hal tersebut tidak mampu dikelola dengan baik, rencanan menjadikan desa kemungsari lor sebagai agrowisata durian dirasa cukup tepat bagi masyarakat karena durian banyak yang meminati dan durian di desanya memiliki kualitas yang cukup baik sehingga peluang untuk menarik pengujung cukup terbuka lebar, hanya tinggal bagaimana pengelola dan desa mengemas dan memprosikan, selain itu masyarakat juga cukup optimis dengan banyak pengunjung akan banyak memberi keuntunga bagi mereka.

\section{Menyusun Instrumen dan Pelaksanan Monev Tahap I (penyiapan dan persiapan agrowisata durian)}

Secara umum monitoring dipahami sebagai suatu proses untuk mengetahui pelaksanaan program yang sedang berjalan, kegiatan monitoring dapat membantu meningkatkan kualitas program dan mengidentifikasi masalah-masalah yang harus di atasi guna mencapai tujuan program. Selain itu monitoring juga dipahami sebagai salah satu bentuk pemantauan terhadap keseluruhan proses pelaksanaan program sehingga diketahui kelemahan dan keunggulan dalam proses pelaksanaan. Seangkan evaluasi dapat dipahamu sebagai kegiatan yang dilakukan untuk menentukan pencapaian secara umum dari sebuah proram, kegiatan evaluasi dapat membantu mengidentifikasi kekuatan dan kelemahan sebuah 
program untuk ditingkatkan dan diperbaiki di masa yang akan datang atau untuk memastikan bahwa program yang telah dilaksanakan mampu mencapai tujuan atau keberhasilan.

Adapun tujuan monev yaitu untuk mengetahui tingkat pencapaian dan keseuaian antara rencana yang telah ditetapkan dengan hasil dari pelaksanaan program tersebut, oleh Karena itu mengingat pentingnya program atau kegiatan yang telah dilaksanakan dalam mewujudkan kemuningsari lor sebagai desa agrowisata durian maka tim pengabdian merasa penyusunan instrument monev dibutuhkan untuk mengetahui seberapa jauh perkembangan dalam penyiapan dan persiapan agrowisata durian di kemuningsari lor, dalam penyusunan intrumen monev tim pengabdian menyusun beberapa indikator monev dan melaksanakan evaluasi pada tiap-tiap kegiatan pengabdian, dalam penyusunan instrument monev tim terlebih dahulu mendiskusikan dan menyepakati bentuk dan isi dari instrument, kemudian dilanjutkan dengan penyusunan. Pelaksanaan monev dilakukan satu kali dalam satu minggu dengan mengacu pada intrumen yang telah dibuat, dalam kegiatan ini tidak terdapat kesulitan karena tim dan masyarakat mampu bekerjasama dengan baik.

\section{KESIMPULAN}

1. Dari hasil pelaksanaan kegiatan kontruksi agrowisata durian yang dilakukan oleh tim pelaksana pengabdian kepada masayarakat kepada pada komunitas atau kelompok petani durian di Kemuningsari Lor, Kecamatan Panti terdapat beberapa hal yang dicapai, yaitu:

2. Organisasi dan kelembagaan telam mampu dipahami sebagai hal yang urgen dan dibutuhkan bagi masyarakat kemuningsari lor dan LKM sebagai Organisasi telah mampu dipahami sebagai wadah pemersatu yang dapat digunakan sebagai alat perjuangan dalam mencapai tujuan bersama.

3. Telah munculnya inisatif dari masyarakat untuk menjadikan potensi durian sebagai komuditas utama dan agrowisata durian sebagai sarana dalam mengelola dan mengoptimalkan potensi durian di kemuningsari lor.

4. Disepakatinya Agrowisata durian sebagai konsep pengembangan masyarakat yang konteks dengan kemuningsari lor.

5. Disepakatinya sistem tata kelola dan tata ruang agrowisata durian yang akséptabel dan berintegrasi.

6. Meningkatnya pengetahuan dalam mengembangkan bibit dan buah yang berkulaitas dan berdaya jual tinggi dan terdapat pohon durian di setiap pekarangan dan kebun penduduk.

7. Mampu memanfaatkan website yang ada sebagai media promosi agrowisata durian. 
8. Terbangun komitmen pemerintah desa dalam mewujudkan agrowisata durian.

9. Diketahuinya capaian pada masing-masing kegiatan dan diketahuinya keseuaian antara rencana yang telah ditetapkan dengan hasil dari pelaksanaan program.

\section{REKOMENDASI}

Berdasarkan hasil dan luaran kegiatan pengabdian kepada masyarakat kepada komunitas petani durian di Desa Kemuningsari Lor Kecamatan Panti Kabupaten Jember, terdapat beberapa hal yang dapat dijadikan saran dan rekomendasi terkait kontruksi agrowisata durian, yaitu:

1. Untuk lebih mengoptimalisasi beberapa kegiatan yang menjadi bagian upaya dalam mengkonstruksi agrowisata durian sebaiknya lebih mengintensifkan pendampingan, khususnya dalam kegiatan pembentukan organisasi dan kelembagaan serta dalam upaya mengkruksi tata kelola dan tata ruang agrowisata, mengingat tidak semua pimpinan kolektif dan anggota LKM memiliki pemahaman keorganisasian, tata kelola agrowisata dan tata ruang agrowisata.

2. Mendorong terjadinya kerjasama multi pihak untuk menunjang kebutuhan dalam pengembangan organisasi dan kebutuhan dalam merealisasi pembentukan agrowisata durian dikemuningsari lor.

3. Mampu menjadikan LKM agrowisata durian sebagai motor penggerak utama dalam pengelolaan potensi durian dari hulu hingga hilir, sehingga mampu menggerakkan ekonomi masyarakat disektor lainnya sebagai penunjang agrowisata. 


\section{DAFTAR PUSTAKA}

BPS Kabupaten Jember. 2015. Statistik Daerah Kecamatan Panti 2015. Jember.

Jayanti, Ni Ketut Dewi Ari, dkk. 2016. Pemanfaatan Teknologi Informasi dalam Meningkatkan Nilai Jual dan Pemasaran UKM Kopi Bali.

Pemdes Kemuningsari Lor. 2017. Data Potensi dan Tingkat Perkembangan Desa. Jember : Pemerintah Desa Kemuningsari Lor.

Universitas Jember. 2018. Laporan KKN Kelompok 37: Peningkatan Potensi Wisata dan Wirausaha Desa Kemuningsari Lor Kecamatan Panti Kabupaten Jember 